\title{
Application of Affective Factors in College English Teaching
}

\author{
Hui Chen \\ Jilin Institute of Chemical Technology \\ Jilin, China
}

\begin{abstract}
Affective factors and classroom atmosphere play important roles in college English teaching. Positive and harmonious classroom atmosphere and friendly affective factors will greatly attribute the efficiency of college English learning. The paper analyses the influences affective factors on and how to serve college English teaching. It aims to respect the teaching-learning principle to improve learning efficiency and promote college English teaching.
\end{abstract}

Keywords-affective factors; application; college English teaching

\section{INTRODUCTION}

In recent years, with the continuous expansion of the university, the diversification trend of the university's students has become increasingly prominent. This form puts new demands on university education, and college English education as a compulsory course faces new challenges. English teachers are struggling to travel to the major teaching buildings, eager to instill textbook knowledge into students, and are forced by heavy teaching tasks and progress. This leads to less attention to the individual differences of students in the course of class, and neglects the emotional care for students. However, psychological experiments and teaching practices have repeatedly proved that affective factors are the key to the success or failure of teaching. Paying attention to the psychological counseling and humanistic care of students is bound to be the focus of college English education and even university education. The emotional teaching model was first developed by the American scholar Krashen's "emotion filtering hypothesis". It is pointed out that in the teaching process; we should pay attention to the emotional trends of both teachers and students, stimulate students' participation awareness and interest in learning, and focus on leading by interest. Learning, thus improving the learning effect, is an orderly progression of college English courses and extracurricular activities, improving the quality of English teaching.

\section{THE INFLUENCE OF AFFECTIVE FACTORS ON COLlEge ENGLish TEACHING}

According to Krashen's "emotional filtering hypothesis", learning can obtain sufficient knowledge energy, but emotional filtering can prevent learners from fully understanding the energy of linguistic knowledge gained by absorption. In other words, the higher the emotional filtering, the less the language is inhaled. The filtering of emotional factors is like a defense system. The higher the defense, the stronger the external factor that can overcome this fortification - the less language input. This shows that a large number of language input is not equal to efficient language absorption. The large number of lectures in the English class does not mean the improvement of students English scores. In the process of second language acquisition, learners are also affected by the emotional factors. We can simplify the student's learning absorption process into the following three stages: whether the student is exposed to enough knowledge input; whether the student can understand the input of knowledge contacted; whether the student is willing to accept the above knowledge input. From these three stages, we can clearly see the crucial role of emotional factors in the learning process of students.

In the process of college English teaching in Chinese universities, the channels for students to learn English are mainly the absorption of in-class knowledge, the participation of classroom activities and the application of extracurricular language and activities. For most students, the main way to reach and learn English is to stay in the classroom. Therefore, the situation of students learning English in the classroom can more objectively explain the influence of emotional factors on college English teaching. There are two main aspects to this impact:

\section{A. The Internal Cause}

China has a vast territory, and the language and customs of different ethnic groups vary greatly. This has resulted in the geographical diversity of college students' students. Because of different origins and different language habits, many students are not standardized in Mandarin and English pronunciation is not correct. After entering the university, the tremendous psychological pressure put on some students due to standardization of English pronunciation, the openness of foreign teachers' classrooms and the differences from other English-speaking areas, especially on those in less developed areas. In college English class, stress, anxiety, and anxiety are the main emotional reactions, which leads to high psychological filtering and great hindrance to the acceptance of language input knowledge. I can't actively participate in the classroom activities; I am ashamed to speak, not to mention the good knowledge of classroom English. Moreover, these students tend to have strong self-respect, because their language problems are afraid of being ridiculed, 
and they are afraid to interact with others. In the long run, they become an isolated individual, which affects students' learning emotions and affects students' learning effects. It is a vicious circle. In addition, students' influence on their learning goals and orientation also affects students' learning initiative and effort. Expectation and students' learning effect is "U" shape. No expectation and high expectations will affect students' learning mood, which in turn affects the learning outcomes of student students.

\section{B. External Factors}

The university students in our country are all models of full-time universities in the school. The campus is the main place for students to learn knowledge and interpersonal communication. The main emotional factors affecting college students are between students and students: whether students live and study in an equal, friendly and harmonious group is very important to the learning mood of college students, and even affects the orderly teaching; students and teachers between: the main communicator of student knowledge is the teacher. It is important that the teacher is fair and just, but it should be people-oriented. It is taught according to the personality characteristics of different students. The student's learning outcomes will be related to the teacher and respected by the teacher. Impact; Intracompetitive competition: Appropriate competition will increase students' interest in learning, but excessive competition will also dampen students' self-esteem.

\section{THE APPLICATION OF AFFECTIVE FACTORS IN COLLEGE ENGLISH ClASSROOM}

\section{A. Creating a Harmonious and Fair Classroom \\ Environment}

Teachers should strive to create a harmonious and friendly classroom atmosphere in the teaching process. The main environment for students to learn knowledge is the classroom, and the atmosphere of the classroom will have a huge impact on the psychology of students. English education in our country still relies mainly on the teaching of teachers. Teachers can't completely get rid of the image of saints on the podium. The teaching of teachers is often blunt. Students are required to fully accept the knowledge and opinions they impart. The distance between teachers and students is great. Teachers should go into the students in the teaching, learn more about the students' ideas, and communicate with them, not only the students' good teachers, but also their beneficial friends, don't impose their own ideas on the students, and fully respect the students' ideas. For some immature ideas should be guided and directed. Appreciation should be encouraged for the progress of students, efforts should be made to improve students' interest in learning, and students should be encouraged to participate in classroom activities and discussions. Teachers should pay more attention to students, help students solve the difficulties encountered in learning and living, eliminate the sense of distance between teachers and students, and promote mutual trust, so as to achieve high teaching results.

\section{B. People-oriented, Teaching Students in Accordance with Their Aptitude}

The individual differences of students are very large. In the process of teaching, teachers should be careful and conscientious, and strive to discover the personality characteristics of students. On the basis of paying attention to comprehensive professors, we must also highlight the characteristics of training. It is necessary to appropriately adjust the teacher's teaching plan according to the different learning characteristics of the students, and choose a fun and vivid language to mobilize the students' interest and enthusiasm for learning, pay attention to the cultivation of students' learning ability and habits, pay attention to the changes of students' emotional factors, encourage students' personality development, and arrange various activities according to the different characteristics of students to improve students' self-confidence and honor.

Classroom is the hall of evangelism, and it is also a place where students are passionate and stimulating. Teachers should not only pay attention to teaching students' knowledge, but also teach by example to teach people the truth. Combine the content of the teaching materials to cultivate students' sentiment, cultivate students' perseverance and good character. The high school is the teacher, the height is the norm, the teacher should infect the students with his own personality charm, profound knowledge, noble sentiment, and subtly make a model for the students.

\section{Reasonable Competition and a Harmonious Environment}

The well has no pressure and no water, and people are not under pressure. In the school environment, teachers should appropriately introduce competition mechanisms to improve students' motivation. Of course, the standards also vary from person to person and cannot be comprehensive. For students with better knowledge, appropriate standards should be raised, and students with lower standards should reasonably lower the standards. The competition mechanism can be expressed in classroom activities, community competitions, or for future planning, discussion, and competition. I refer to the "old me" reference. As long as I surpass the old one, I should commend the rewards in a timely manner.

A harmonious and relaxed classroom environment enables students to enjoy a safe, warm learning environment and reduce student emotional filtering. Pleasant voices, warm smiles, moderate body language and eye contact can all eliminate students' nervous and anxious moods. English classes are more communicative than other subjects, and teachers should make full use of this. Actively communicate emotionally with students, promote emotional interaction with students, and develop learning emotions and motivation for students' learning.

\section{Optimizing Classroom Mood}

After a long period of study, students will inevitably experience slack and even confusion. The teacher should appease the students' anxiety and provide a reference plan for 
the future development of the students, helping to analyze the development prospects of the profession and the current status of the job market, guide students to the society in the future, understand the changes in students' emotions, lead the individual as a whole, and provide students with a positive, motivated future goal. It is also necessary to mobilize the students' learning motivation in a timely manner, change the students' learning thoughts, and enable the students to actively study. From the time I want to learn, I need to learn from teachers and students.

\section{CONCLUSION}

Emotion may not be ignored. Paying attention to the influence of emotional factors on the classroom can promote students' enthusiasm for learning and improve students' learning motivation. Respecting the rules of teaching and using the rules will make the teaching get twice the result with half the effort.

\section{REFERENCES}

[1] Chen Lin. Construction of positive emotional factors in college English teaching $[\mathrm{J}]$. Journal of changchun university of science and technology. 2010(07)

[2] Hong Junbin. On emotional teaching in college English [J]. Journal of mudanjiang institute of education. 2007(06)

[3] Ma Yan. Cultivation of emotional factors and construction of harmonious college English class [J].Science and technology style. 2010(24)

[4] Ren Zhixin. Emotional factors and college English teaching [J]. Journal of liaoning institute of education administration. 2010(02)

[5] Tian Chunguang. Emotional factors and college English teaching [J]. Journal of binzhou university. 2007(04)

[6] Wang Xiaojun. Influence of emotional factors on English classroom teaching [J]. Journal of changchun institute of education. 2008(03)

[7] Xiang Ling. Emotional factors and teaching strategies in college English teaching $[\mathrm{J}]$. Journal of hubei correspondence university. 2006(03)

[8] Xu Yingcai. On emotional factors in college English teaching and its teaching strategies $[\mathrm{J}]$.China science and education innovation guide. 2011(19)

[9] Zhang Rongmei. Teaching strategies to stimulate learning motivation in oral English teaching [J]. Journal of donghua university (social science edition). 2005(02)

[10] Zhao Changzhi. Analysis of emotional factors in English classroom teaching $[\mathrm{J}]$. Journal of qinghai normal university (philosophy and social sciences edition). 2008(02) 